\title{
Karel Krejčí o Rękopisie znalezionym w Saragossie Jana hr. Potockiego
}

\author{
Krystyna Kardyni-Pelikánová
}

\begin{abstract}
Abstrakt
W związku z dwóchsetną rocznicą śmierci oświeceniowego pisarza, podróżnika i badacza Jana Potockiego autorka przypomina o dotyczących Rękopisu, interesujących i cennych pracach, które wyszły spod pióra znakomitego czeskiego polonisty i komparatysty Karela Krejčego na początku lat siedemdziesiątych ubiegłego wieku. Na przykładzie owych prac usiłuje ukazać, jak ich autor realizował swój projekt powiązania osiągnięć czeskiego strukturalizmu z genologiczną i historyczno-rozwojową analizą dzieła jako gatunku literackiego.
\end{abstract}

\section{Kluczowe słowa}

Jan Potocki; Karel Krejčí; powieść europejska; recepcja literatury polskiej w Czechach

\section{Abstract \\ Karel Krejčí on The Manuscript Found in Zaragoza/Saragossa by Jan Count Potocki}

In relation to the 200 anniversary of the death of the enlightened writer, traveller, and researcher Jan Potocki the authoress reminds us of the interesting and valuable works concerning the Manuscript written by a brilliant Czech specialist in Polish and comparative studies Karel Krejči at the beginning of the 1970s. At the example of the works she tries to demonstrate how their author realised his proposal to connect the achievements of Czech structuralism with genre and historical-evolutionary analysis of a literary artefact as a literary genre.

\section{Key words}

Jan Potocki; Karel Krejčí; European novel; reception of Polish literature in the Czech environment 
Kiedy bierze się do ręki polski przekład Święta nieistotności - ostatniej na razie książki znanego dziś w świecie pisarza czeskiego Milana Kundery (dawniej piszącego po czesku, dziś po francusku), kiedy czyta się na jej okładce słowa francuskiego krytyka, pełne zachwytu dla wspaniałej francuszczyzny Czecha, która, jak twierdzi Francuz, potrafi wywołać u odbiorcy spazm wzruszenia i śmiechu zarazem, mimowolnie w czytelniku polskim rodzi się pytanie: a co polscy twórcy? Jak oni wchodzili (poza przekładami) w kulturę zachodnioeuropejską, jak się tam odnajdywali? Czy, a jeśli tak, to czym ją wzbogacali?

Pewną odpowiedź na pytanie owo można znaleźć już u Stanisława Przybyszewskiego, który kiedyś zauważył (cytuję z pamięci): ,jest nas trzech piszacych z sukcesem w jezykach obcych: Apollinaire-Kostrowicki po francusku, Conrad-Korzeniowski po angielsku i ja po niemiec$k u$ ". Stwierdzenie to - tym razem jako sąd Apollinaire'a, inspiratora ważnych nurtów w sztuce europejskiej - przypomniał też W. Sadkowski w artykule Czy Apollinaire byt Polakiem?ํㅜ Cała trójka wniosła do literatury europejskiej wiele nowego (także z punktu widzenia przyswojonego sobie języka), świadcząc o tym, że „Polak (też) potrafi”. Potwierdzałoby to mniemanie znakomitego czeskiego polonisty, badacza literatury polskiej i czeskiej, komparatysty i socjologa literatury, Karela Krejčego (1904-1979), iż „literatura polska należy do najwybitniejszych literatur świata zarówno z uwagi na swój wyraźny charakter narodowy, jak i dla wielkiego wktadu w skarbiec kultury światowej". ${ }^{2}$

Znane przysłowie rosyjskie radzi, by taniec zaczynać od pieca. Nie chcę wprawdzie sięgać zbyt daleko w gląb dziejów, ale nie sposób jednakże pominąć np. polskiego odrodzenia, o którym tak pięknie mówił tenże Karel Krejčí, podziwiając wyłaniający się z ówczesnej polskiej twórczości obraz Polaka: „... znoszacego ze spokojem życie i śmierć, szczéście $i$ nieszczęście, $i$ znajdujacego pojednawcze wyjście nawet z ostrych kryzysów osobistych. Światto i cień, szczeście, spokój, mitość, ból i nieszczeście tworza tutaj harmonijna catość świadomego żywota cztowieka, który wie, po co żyje, którego droga życiowa nie traci sensu. Ten zrównoważony optymizm jest rysem, który w dalszym rozwoju przestanie być dominanta polskiej literatury, miotajacej sie w walkach $i$ cierpieniach, ale pojawia sie ciagle od nowa, zwłaszcza w dziełach szczytowych, najlepiej wyrazajacych polskie życie..."3

Jak tu przy okazji nie przypomnieć jeszcze choćby znanych szesnastowiecznej Europie dzieł Frycza-Modrzewskiego czy łacińskiej poezji Sarbiewskiego, długo uznawanego w Anglii za „nowego Horacego”? A w oświeceniu i później w ciagu dalszych dwu wieków sporo zamieszania wywołał pisany po francusku, opublikowany zrazu anonimowo utwór, pod który podszywali się i pisarze francuscy (np. romantyk Charles Nodier) - właśnie ów wymieniony w tytule Rękopis znaleziony w Saragossie, znany szerokiej publiczności także (a może przede wszystkim) ze świetnej, wielokrotnie nagradzanej adaptacji filmowej Wojciecha Hassa sprzed 50 lat (premiera 1965). Napisane przez Polaka dzieło uznawane bywało przez wielu krytyków za jedno z najświetniejszych dzieł europejskiego oświecenia czy też nawet za jedną z najwybitniejszych powieści w dziejach literatury.

1 SADKOWSKI, Wacław: Czy Apollinaire byt Polakiem? Res Humana, 2015, nr 1, s. 41-43. Por. też: SADKOWSKI, Wacław: Rozdroża mitości Guillaume'a Apollinaire'a (Wilhelma Apolinarego Kostrowickiego). Opowieść epistolograficzna, Warszawa: Wydawnictwo Studio EMKA, 2014.

2 KREJČÍ, Karel: Dějiny polské literatury. Praha: Československý spisovatel, 1953, s. 9.

3 Ibidem, s. 76 [tłumaczenie i podkreślenie - K. K.-P.]. 
W 2015 roku przypominaliśmy sobie dwóchsetlecie samobójczej śmierci jej autora: Jana hr. Potockiego. Okragłą rocznicę upamiętniono w Polsce nie tylko pięknym wydaniem samego dzieła w nowym, chwalonym przez recenzentów przekładzie Anny Wasilewskiej (uznanym za dużo bliższy francuskojęzycznemu oryginałowi i zamierzeniom autora niż poprzedni przekład dziewiętnastowieczny), ale i wieloma pracami naukowymi, które od czasu monografii A. Brücknera Jana Potockiego prace $i$ zastugi naukowe z 1911 roku oraz reaktywacji pamięci o polskim autorze jako twórcy jednego z najbardziej interesujących utworów fantastycznych w skali światowej przez Rogera Caillois, przyniosły szereg nieznanych faktów z dziejów powstawania utworu oraz ważną wiadomość o odnalezieniu jego drugiej, późniejszej wersji z 1810 roku. Czasopismo Literatura na Świecie poświęciło twórcy dzieła w rocznikach 2014 (nr 11-12) i 2015 (7-8) specjalne numery, ale jakoś przeoczono, jak się wydaje, sprawę niebanalnej recepcji tego utworu w Czechach.

A u południowych sąsiadów właśnie już od 1973 roku krąży przecież po bibliotekach świetne czeskie tłumaczenie Rękopisu z objaśnieniami i posłowiem K. Krejčego, ${ }^{4}$ który dziełu temu poświęcił na początku lat siedemdziesiątych XX wieku sporo literaturoznawczej uwagi. Niewydane dotąd książkowo prace uczonego wyszły ostatnio w Pradze, zebrane w potężnym, redagowanym przez Marcela Černego tomie Karel Krejčí: Literatury a žánry v evropské dimenzi. Nejen česká literatura v zorném poli komparatisty (Praha, 2014). Do tomu tego włączone zostały rozprawy i drobniejsze uwagi profesora, dotyczące dziedzin komparatystyki, slawistyki, polonistyki, bohemistyki, tematologii, ale i studiów związanych z tematyką literacką Europy Środkowej, a także czasopiśmiennicze publikacje sporo mówiące o metodologii prac historycznoliterackich. Centralnym punktem badań w poszczególnych pracach praskiego polonisty nie bywał wyłącznie sam tekst, ale i jego szeroko rozumiany kontekst. Nic dziwnego, że w tomie tym tak właśnie zostało ujęte i obszerne studium: Román Jana hraběte Potockého, jeho genologie a genealogie. ${ }^{5}$ Mówiąc nawiasem szkoda tylko, że w skład tej edycji nie wszedł także opublikowany przed laty w Twórczości, polski artykuł Krejčego o Balladynie Juliusza Słowackiego, ${ }^{6}$ w którym badacz z niezwykłą erudycją i pomysłowością analizował przenikające się nawzajem w tym dramacie inspiracje oświeceniowe i romantyczne. Artykuł ten był jednym z wcześniejszych przejawów zainteresowań Krejčego historycznymi zmianami zachodzaccymi w prądach i kształtach (cz. tvary) literackich, a odkrywanymi w ważnych utworach literatury europejskiej czy euroatlantyckiej. Szkoda jest o tyle duża, że Balladyna jako jeden z niewielu polskich dramatów romantycznych bywał w Czechach wystawiany kilka razy i niestety nie odnosił nigdy sukcesu. Zapewne powstawały w tym wypadku jakieś bariery recepcyjne. Starałam się kiedyś wyjaśnić przyczyny tego faktu pisząc o polskich sztukach na scenach brneńskich. ${ }^{7}$

4 POTOCKI, Jan hr.: Rukopis nalezený v Zaragoze. Přel. Jaroslov Simonides. Doslovem a vysvětlivkami doprovodil Karel Krejčí. Praha: Odeon, 1973.

5 KREJČÍ Karel: Román Jana hraběte Potockého, jeho genologie a genealogie. In: KREJČÍ, Karel: Literatury a žánry v evropské dimenzi. Praha: Slovanský ústav AV ČR - Euroslavica, 2014, s. 333-354.

6 KREJČÍ Karel: Jeszcze kilka stów o ludowości "Balladyny”. Twórczość 15, 1959, nr 9, s. 83-95.

7 KARDYNI-PELIKÁNOVÁ, Krystyna: Polskie sztuki na scenach brneńskich (od Wandurskiego do Gombrowicza). In: Poláci v Brně a na jižní Moravě. Eds. R. Madecki - L. Štěpán. Brno: Středoevropské centrum slovanských studií, 2008, s. 93-114. 
Lata siedemdziesiąte XX wieku w Czechach, kiedy praski polonista opublikował swe prace o Rękopisie, to początek tzw. „normalizacji Husakowskiej”, która nastąpiła po załamaniu się Praskiej Wiosny z 1968 roku. To od tego, znamiennego dla Czechów roku Krejčí zaczął mawiać o sobie z zaprawionym goryczą humorem, że jest chyba jedynym „polonistą habilitowanym i rehabilitowanym”. Dodajmy, że habilitował się jako polonista pracą Polská literatura ve vírech revoluce w 1935 roku. Po wojnie, po otrzymaniu profesury i wielu innych wyróżnień naukowych przejął w 1954 roku kierownictwo polonistyką praską na Uniwersytecie Karola IV po Marianie Szyjkowskim (1883-1952), u którego w Pradze odbył studia polonistyczne, doktoryzował się i obronił dysertację habilitacyjną z literatury polskiej. W czasach ortodoksyjnego stalinizmu, który w Czechach nastał po przewrocie komunistycznym w 1948 roku i trwał znacznie dłużej niż w Polsce, po poparciu - jako prorektor UK - studentów walczących o swobodę wypowiedzi naukowej został oskarżony o „działalność zagrażająca państwu” i otrzymał zakaz kontaktu ze studentami. Podjął wówczas pracę w Czechosłowackiej Akademii Nauk. Praska Wiosna rehabilitowała go, ale do pracy na Uniwersytecie Karola już nie powrócił, poświęcając się całkowicie prowadzonym w Akademii badaniom naukowym.

W działalności naukowej Krejčego początek lat siedemdziesiątych ubiegłego wieku to jednocześnie doba wzmożonego zainteresowania profesora historycznym procesem przemian poszczególnych form literackich i pełnionych przez nie funkcji semantycznych, a była to sprawa, której, jak sądzil, nie rozwiązali w sposób dostateczny zyskujący rozgłos i sławę w międzywojniu prascy strukturaliści. Krejčí bardzo wcześnie zaczął rozważać problem zespolenia osiagnnięć badawczych praskiej szkoły strukturalnej z socjologiczną i historyczną interpretacją dzieła literackiego, ${ }^{8}$ bowiem pod wpływem Szyjkowskiego, ale i czeskich badaczy pozytywistów, nie przyjął wyłącznie ergocentrycznej postawy czeskiego strukturalizmu międzywojennego. Uznając pozytywistyczną zasadę dokładności gromadzenia materiału badawczego, zwracał jednocześnie uwagę i na przemiany jego kształtów oraz rozwój owych form w czasie historycznym, sięgając po metody komparatystyczne. Już w 1964 roku opublikował pisaną pod tym kątem widzenia, wielką księgę o Heroikomice v básnictví [poezji] Slovanü.

W latach kolejnych centralnym punktem w jego badaniach zaczynała stawać się proza europejska, którą analizował śledząc jej rozwój gatunkowy i wzajemne powinowactwa („genologia i genealogia”, jak brzmi to w nazewnictwie profesora). I właśnie pod takim kątem widzenia - odkrywania i typologii gatunków, jakich elementy wchłonęło w siebie niezwykłe dzieło Jana Potockiego, oraz poszukiwań „genealogii”, czyli rodowodu tej powieści w odniesieniu do powieści europejskiej - analizowal Krejčí Rękopis w obszernym studium, opublikowanym w Slavii $^{9}$ a przetłumaczonym przez mnie na język polski

8 NIEDZIELA, Zdzisław: Marian Zdziechowski a Karel Krejči, twórcy nowoczesnej bohemistyki i polonistyki. In: Slovanský a středoevropský literární kontext. Praha, 1991, s. 24; też FORKOVÁ-MATĚJKOVÁ, Veronika: Karel Krejči a metodologie literárni vědy aneb Proč jsem se nestal strukturalistou. In: Slavistika dnes: vlivy a kontexty, Praha: Červený Kostelec - Pavel Merhart, 2008, s. 465-474.

9 KREJČÍ, Karel: Román Jana hraběte Potockého, jeho genologie a genealogie. Slavia 40, 1971, č. 4, s. 554-576. 
i opublikowanym w piśmie Litteraria Humanitas VIII. ${ }^{10}$ Trzy lata po pierwszej publikacji studium o Rękopisie badacz wydał jego francuski skrót. ${ }^{11}$

W swej pracy - prócz wykrywania filiacji genologicznych, zbliżonych w swej istocie do badań nazwanych przez Stefanię Skwarczyńską „instrumentacja rodzajowa dzieta” ${ }^{12}$ oraz do poglądów Milana Kundery, który pisał: „W dziele każdego powieściopisarza tkwi skrycie wizja historii powieści, idea tego, czym powieś́ jest"13 - Krejčí starał się włączyć utwór Potockiego w proces historycznoliteracki, zaznajomić odbiorcę z literackim kontekstem czasowym, z którego się Rękopis stopniowo (i wielokrotnie) wynurzał na powierzchnię życia literackiego.

Trudno dziś stwierdzić, czy na zainteresowanie profesora Rękopisem wplynął w jakiś sposób pewien fakt z jego własnego życiorysu. Otóż w międzywojniu Krejčí zbliżył się czy wręcz wstąpił, jak o tym pisze Jiří Bečka, do czeskiego wolnomularstwa, ${ }^{14}$ o czym po wojnie ze zrozumiałych względów raczej nie wspominał. W każdym razie omawiając w swym studium o Rękopisie kompozycję tej powieści, dostrzegł wyraźny związek jej struktury z rytuałem przyjmowania do lóż wolnomularskich, poświęcając obecności wątków wolnomularskich w literaturze europejskiej pokaźny fragment swej rozprawy.

Czeską wersję powieści Potockiego przygotował doświadczony tłumacz, Jarosław Simonides, na podstawie przekładu i wydania jej w 1847 roku przez Edmunda Chojeckiego, który nota bene również w dziejach kontaktów polsko-czeskich ma swoją piękną, a miejscami nie dość wyjaśnioną kartę. Uczestnik Zjazdu Słowiańskiego w Pradze w 1848 roku (skąd został wydalony za nadmierny radykalizm) był autorem dwutomowej pracy Czechja $i$ Czechowie, w której jako pierwszy z Polaków dostrzegł i docenił tak dziś przez nas lubiany i podziwiany humor w czeskiej twórczości literackiej, a także w czeskim charakterze czy tożsamości narodowej, kształtującej się wówczas, po kilkuwiekowej zapaści, na nowo, wśród nowej elity, wywodzącej się z warstw chłopskich, drobnomieszczańskich i plebejskich (tzw. Odrodzenie Narodowe); Chojecki tego rozwarstwienia społecznego nie dostrzegał dzieląc polskim zwyczajem zbiorowość czeską na chłopów i elitę umysłową. Pisał wówczas: „Gtówna charakterystyka wieśniaka czeskiego, jak się przekonujemy o tem z jego pieśni, jest ironia. Zszedtszy sie z cztowiekiem wyżzzego wyksztatcenia Czech udaje nieuka, i niepojetego, przez ten czas śledzi go, bada, poznaje, a gdy wróci do domu, wypowiada wszystkie śmieszności, okraszone wtasnemi, nieukowemi uwagami." ${ }^{15}$

To przeświadczenie zyskał, być może, nie tyle z autopsji, ile poprzez swój kontakt z czeskim satyrykiem Karelem Havlíčkiem, który uczył go czeskiego i któremu kilka

10 KARDYNI-PELIKÁNOVÁ, Krystyna: przekład: K. Krejčí, Powieś́́ Jana hr. Potockiego, jej genologia i genealogia. Litteraria Humanitas VIII. Brno: Masarykova univerzita, 2000, s. 207-234.

11 KREJČÍ, Karel: Le roman du comte Jean Potocki, sa genologie et sa généalogie, „Le Cahiers de Varsovie“ 3. Varsovie, 1974, s. 209-216.

12 SKWARCZYŃNSKA, Stefania: Szczególny typ instrumentacji rodzajowej utworu literackiego (Le Rêve Emila Zoli, La Jalousie Alaina Robbe-Gilleta). In: SKWARCZYŃNSKA, Stefania: Wokół teatru i literatury. Warszawa, 1970, s. 252-274.

13 KUNDERA, Milan: Sztuka powieści. Tłum. Marek Bieńczyk. Warszawa, 1998.

14 BEČKA, Jiř́: Karel Krejčí mezi proudy. Slavia 73, 2004, nr 4, s. 397-410.

15 CHOJECKI, Edmund: Czechja i Czechowie. Lipsk, 1847, t. II, s. 156. 
lat później proponował współpracę z Mickiewiczowską „Trybuną Ludów”. I jego własna twórczość, już jako autora francuskiego Charlesa Edmonda, twórcy sztuk odnoszących sukcesy na scenach paryskich, trafiała w Czechach na powikłania: nie jest dość jasne na przykład, czy jego utwór La Florentine tłumaczyła niezmiernie dla Czechów ważna pisarka, Bożena Němcová, czy też nazwisko jej kryło jedynie właściwego tłumacza - polityka F. L. Riegra, który się zresztą z czasem do przekładu przyznał, publikując go już pod własnym nazwiskiem. ${ }^{16}$

Podobnie jak z Florentynka ma się sprawa i z Rękopisem, istnieją bowiem dziś coraz mocniej uzasadnione domniemania, że polskiego przekładu Rękopisu dokonał ktoś inny, nieznany, a Chojecki jedynie użyczył publikacji swego nazwiska. ${ }^{17}$ Krejčí na początku lat siedemdziesiątych, nie znając późniejszych faktów, przyjmował w swoim studium za Leszkiem Kukulskim ${ }^{18}$ zdecydowanie autorstwo Chojeckiego.

Powieść Jana Potockiego wyraźnie czeskiego badacza fascynowała. Wracał też do niej kilkakrotnie. Oprócz wspomnianego studium i jego francuskiego skrótu napisał także interesujące posłowie do tłumaczenia czeskiego, zatytułowane Rukopis nalezený v Zaragoze a jeho autor. Wiele spraw dotyczących powiązań powieści z literaturą europejska, a więc jej intertekstualności, badacz podał w obu pracach w sposób zbliżony, choć oczywiście poetyka ich jest wyraźnie sfunkcjonalizowana wobec odbiorcy: w pierwszym wypadku odbiorcy z kręgów naukowych, w drugim - spośród szeroko pojętej, ale ambitnej publiczności czytającej.

Nowością - w porównaniu z rozprawką zamieszczoną w Slavii - jest stwierdzenie, ze powieść, po odrzuceniu wstawek, jawi się jako kontrapunkt dwu fabuł, które się wzajemnie krzyżują, zbliżając się ku sobie lub od siebie oddalając, a które różnią się zasadniczo nie tylko występującymi w nich postaciami oraz losami własnych opowiadaczy a jednocześnie bohaterów w jednej osobie, ale i całą budową, koncepcją osób działających, umieszczeniem w czasie i przestrzeni. Tymi dwiema głównymi fabułami są dzieje van Wordena i Avadora. Wprawdzie technika opowiadania w obu wypadkach jawi się jako bardzo zbliżona: jest to w zasadzie wolne zestawienie szeregu przygód, ale bohater pierwszej głównej fabuły, van Worden, dąży do jakiegoś celu, podczas gdy funkcją Avadora jest odwracanie uwagi czytelnika od tego faktu.

W posłowiu Krejčí ze szczególną siłą podkreśla oryginalne wykorzystanie przez Potockiego fantastycznej groteskowości, dzięki czemu odbiorca odnosi wrażenie, że autor prowadzi dość wyraźnie swą oświeceniową powieść ku dopiero rodzącemu się prądowi romantycznemu. Owa fantastyczna groteskowość jest najważniejszym rysem akcji podstawowej, tzn. tej, której bohaterem jest van Worden. Odróżnia ją to nie tylko od wszyst-

16 Por. KARDYNI-PELIKÁNOVÁ, Krystyna: Překládala Božena Němcová hru Edmunda Chojeckého „La Florenti$n e$ “? In: Václavkova Olomouc 1978. Praha, 1982, s. 165-171.

17 WASILEWSKA, Anna: Stowo od ttumaczki. In: POTOCKI, Jan: Rękopis znaleziony w Saragossie. Kraków, 2015, s. 768-778; także badacze francuscy : Rękopis znaleziony w Saragossie. Nowe ttumaczenie ostatniej wersji autorskiej z 1810 roku. Oprac. Fronçois Rosset - Dominique Triaire. Kraków, 2015; ROSSET, François TRIAIRE, Dominique: Wstęp. In: Jan Potocki: Rękopis znaleziony w Saragossie. Kraków, 2015, s. 5-27; ROSSET François - TRIAIRE, Dominique: zamieszczona w tym wydaniu Rękopisu Bibliografia, 2015, s. $744-750$.

18 KUKULSKI, Leszek: wstęp i przypisy in: Potocki Jan: Rękopis znaleziony w Saragossie. Warszawa, 1965. 
kich wątków pobocznych, ale i od akcji drugiej - wątku przygód Alvadora. Właśnie owo specyficzne połączenie fantastyki z groteską wywołuje, zdaniem Krejčego, wrażenie oryginalności i nowości w powieści Potockiego. Wprawdzie z pierwiastkami fantastycznymi i komicznymi spotykamy się również w wątkach ubocznych, ale tam ujęte są one w sposób tradycyjny, nie przenikając się wzajemnie. Są po prostu „oboksiebne”. Natomiast w akcji głównej, argumentował Krejčí, jest inaczej. Tutaj autor bawi się w sposób widoczny powracającymi motywami, które sprowadza z płaszczyzny heroicznej na płaszczyznę groteskowego paradoksu. Tak na przykład dzieje się z pojęciem honoru, które przewija się przez całą powieść (co badacz wiąże z jej rycersko-hiszpańskim kolorytem). Pojęcie to $\mathrm{w}$ sensie szlachetnym, w tonacji podniosłej występuje w związku z osobą van Wordena. Ale już w odniesieniu do ojca protagonisty nabiera odcienia śmieszności, by zostać doprowadzonym do całkowitego absurdu w motywie najemnego mordercy, który zabija obu swoich powaśnionych z sobą mocodawców (pobrawszy od obu za to z góry zapłatę) i czynem tym wykazuje swoją solidność zawodową, pojmowaną przezeń jako poczucie honoru.

W wyniku długiego obcowania z utworem Jana Potockiego Krejčí nie zawahał się napisać, iż dzieło to jest „bez wątpienia jednym z najbardziej oryginalnych dzieł, jakie posiada literatura europejska owych czasów”, a oryginalność jego wynika przede wszystkim ze struktury powieści, twórczo łączaccej różne rodzaje ówczesnej prozy fabularnej.

A o tym, że utwór Potockiego nie pokrywa się kurzem w magazynach czeskich bibliotek, świadczy fakt, iż w 2015 roku w programie Vltava czeskiego radia emitowano wieloodcinkowe, głośne czytanie Rękopisu. Audycje przygotowała Milena Marešová.

\section{Literatura}

BEČKA, Jiří: Karel Krejči mezi proudy. Slavia 73, 2004, nr 4, s. 397-410.

BRÜCKNER, Aleksander: Jana Potockiego prace i zastugi naukowe. Warszawa, 1911.

CHOJECKI, Edmund: Czechja i Czechowie. Lipsk, 1847.

FORKOVÁ-MATĚJKOVÁ, Veronika: Karel Krejči a metodologie literární vědy aneb Proč jsem se nestal strukturalistou. In: Slavistika dnes: vlivy a kontexty. Praha: Červený Kostelec - Pavel Merhart, 2008, s. 465-474.

FORKOVÁ-MATĚJKOVÁ, Veronika: Komparativni pristupy Karla Krejčího v jeho pojeti české a polské literatury. Filozofická fakulta, Ústav české literatury a literární vědy, Dějiny české literatury a teorie literatury, dizertační práce, 2012.

KARDYNI-PELIKÁNOVÁ, Krystyna: Polskie sztuki na scenach brneńskich (od Wandurskiego do Gombrowicza). In: Poláci v Brně a na jižni Moravě. Eds.: Roman Madecki - Ludvík Štěpán. Brno: Středoevropské centrum slovanských studií, 2008.

KARDYNI-PELIKÁNOVÁ, Krystyna: Překládala Božena Němcová hru Edmunda Chojeckého „La Florentine"? In: Václavkova Olomouc 1978. Praha, 1982.

KARDYNI-PELIKÁNOVÁ, Krystyna: przekład: K. Krejčí, Powieść Jana hr. Potockiego, jej genologia i genealogia. Litteraria Humanitas VIII. Brno: Masarykova univerzita, 2000, s. 207-234.

KREJČÍ, Karel: Polská literatura ve virech revoluce. Praha: Orbis,1934. 
KREJČÍ, Karel: Dějiny polské literatury. Praha: Československý spisovatel, 1953.

KREJČÍ, Karel: Jeszcze kilka stów o ludowości „Balladyny”. Twórczość 15, 1959, nr 9, s. 83-95.

KREJČÍ, Karel: Heroikomika v básnictvi Slovanů. Praha, 1964.

KREJČÍ, Karel: Roman Jana hraběte Potockého, jeho genologie a genealogie. Slavia 40, 1971, nr 4, s. $554-576$.

KREJČÍ, Karel: Le roman du comte Jean Potocki, sa genologie et sa généalogie. „Le Cahiers de Varsovie“ 3. Varsovie, 1974, s 209-216.

KREJČÍ, Karel: Powieść Jana hr. Potockiego, jej genologia i genealogia. Przeł. K. Kardyni-Pelikánová. Litteraria Humanitas VIII. Brno: Masarykova univerzita, 2000, s. 207-234.

KREJČÍ, Karel: Literatury a žánry v europské dimenzi. Nejen česká literatura v zorném poli komparatysty. Praha: Slovanský ústav AV ČR - Euroslavica, 2014.

KREJČÍ, Karel: Román Jana hraběte Potockého, jeho genologie a geneakogie. In: KREJČÍ, Karel: Literatury a žánry v evropské dimenzi. Praha: Slovanský ústav AV ČR - Euroslavica, 2014, s. 333-354.

KUKULSKI, Leszek: wstęp i przypisy w: POTOCKI, Jan: Rękopis znaleziony w Saragossie. Warszawa, 1965.

KUNDERA, Milan: Sztuka powieści. Tłum. Marek Bieńczyk. Warszawa, 1998.

KUNDERA, Milan: Święto nieistotności. Przełożył Marek Bieńczyk. Warszawa, 2015.

NIEDZIELA, Zdzisław: Marian Zdziechowski a Karel Krejčí, twórcy nowoczesnej bohemistyki i polonistyki. In: Slovanský a středoevropský literární kontext. Praha, 1991, s. 20-24.

POTOCKI, Jan hr.: Rękopis znaleziony w Saragossie. Warszawa, 1965.

POTOCKI, Jan hr.: Rukopis nalezený v Zaragoze. Přel. Jaroslov Simonides. Doslovem a vysvětlivkami doprovodil Karel Krejčí. Praha: Odeon, 1973.

Rękopis znaleziony w Saragossie. Nowe ttumaczenie ostatniej wersji autorskiej z 1810 roku. Oprac. Fronçois Rosset - Dominique Triaire. Kraków, 1015.

ROSSET, François - TRIAIRE, Dominique: Wstęp. In: POTOCKI, Jan: Rękopis znaleziony w Saragossie. Kraków, 2015, s. 5-27.

ROSSET, François - TRIAIRE, Dominique: zamieszczona w tym wydaniu Rękopisu Bibliografia, 2015, s. 744-750.

SADKOWSKI, Wacław: Czy Apollinaire byt Polakiem? Res Humana, 2015, nr 1, s. 41-43.

SADKOWSKI, Wacław: Rozdroża mitości Guillaume'a Apollinaire'a (Wilhelma Apolinarego Kostrowickiego). Opowieść epistolograficzna, Warszawa: Wydawnictwo Studio EMKA, 2014.

SKWARCZYŃNSKA, Stefania: Szczególny typ instrumentacji rodzajowej utworu literackiego (Le Rêve Emila Zoli, La Jalousie Alaina Robbe-Gilleta). In: Taż: Wokół teatru i literatury. Warszawa, 1970, s. 252-274.

WASILEWSKA, Anna: Stowo od ttumaczki, in: Jan Potocki, Rękopis znaleziony w Saragossie, Kraków, 2015, s. $768-778$.

Prof. dr hab. Krystyna Kardyni-Pelikánová, DrSc.

Kneslova 10, 61800 Brno, Česká republika

pelikanova.kristyna@seznam.cz 